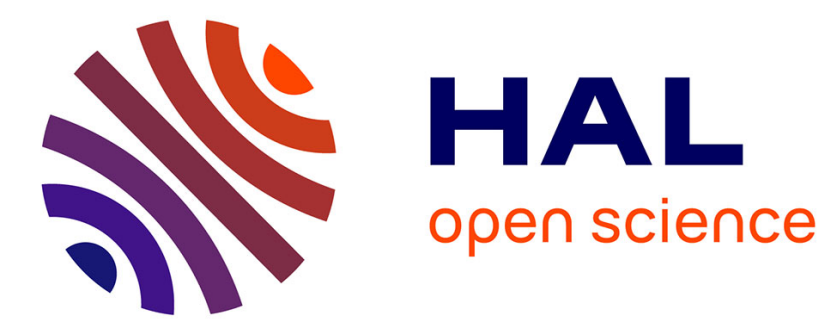

\title{
Active Folding Along A Rift-Flank: The Catania Region Case History (Se Sicily)
}

Stefano Catalano, Salvatore Torrisi, Giuseppe Tortorici, Gino Romagnoli

\section{To cite this version:}

Stefano Catalano, Salvatore Torrisi, Giuseppe Tortorici, Gino Romagnoli. Active Folding Along A Rift-Flank: The Catania Region Case History (Se Sicily). Journal of Geodynamics, 2010, 51 (1), pp.53. 10.1016/j.jog.2010.08.001 . hal-00701257

\section{HAL Id: hal-00701257 https://hal.science/hal-00701257}

Submitted on 25 May 2012

HAL is a multi-disciplinary open access archive for the deposit and dissemination of scientific research documents, whether they are published or not. The documents may come from teaching and research institutions in France or abroad, or from public or private research centers.
L'archive ouverte pluridisciplinaire HAL, est destinée au dépôt et à la diffusion de documents scientifiques de niveau recherche, publiés ou non, émanant des établissements d'enseignement et de recherche français ou étrangers, des laboratoires publics ou privés. 


\section{Accepted Manuscript}

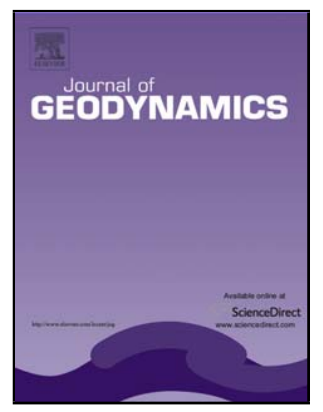

Title: Active Folding Along A Rift-Flank: The Catania Region

Case History (Se Sicily)

Authors: Stefano Catalano, Salvatore Torrisi, Giuseppe

Tortorici, Gino Romagnoli

PII:

S0264-3707(10)00114-6

DOI:

doi:10.1016/j.jog.2010.08.001

Reference:

GEOD 1016

To appear in:

Journal of Geodynamics

Received date:

30-11-2009

Revised date:

29-7-2010

Accepted date:

14-8-2010

Please cite this article as: Catalano, S., Torrisi, S., Tortorici, G., Romagnoli, G., Active Folding Along A Rift-Flank: The Catania Region Case History (Se Sicily), Journal of Geodynamics (2010), doi:10.1016/j.jog.2010.08.001

This is a PDF file of an unedited manuscript that has been accepted for publication. As a service to our customers we are providing this early version of the manuscript. The manuscript will undergo copyediting, typesetting, and review of the resulting proof before it is published in its final form. Please note that during the production process errors may be discovered which could affect the content, and all legal disclaimers that apply to the journal pertain. 


\section{ACTIVE FOLDING ALONG A RIFT-FLANK: THE CATANIA REGION CASE HISTORY (SE SICILY)}

Stefano Catalano, Salvatore Torrisi, Giuseppe Tortorici \& Gino Romagnoli

Dipartimento di Scienze Geologiche, Università di Catania, C.so Italia, 55, 95129 Catania, Italy E-mail addresses: catalano@unict.it (S. Catalano) Tel.-Fax.: +39 0957195714 
Abstract

In this paper a new kinematic and dynamic model on the Recent and active contractional deformation of the Catania region, eastern Sicily, is discussed. The study area represents one of the most seismically active region of the Mediterranean, located at the intersection between the front of the Sicily collision belt and the seismogenic Siculo-Calabrian Rift-Zone. The analysed contractional tectonics form an active triangle zone that originated from the tectonic inversion of a Lower-Middle Pleistocene extensional basin, which was located at the northern edge of the African foreland. The triangle zone consists of two antithetic ENE-WSW oriented thrust-ramps that show evidence of motion during the Holocene and bound a folded belt that involves alluvial deposits as young as 40 ka. These contractional structures represent the final product of the positive tectonic inversion of extensional features located, in the Hyblean Plateau in SE Sicily, along the flank of the active riftzone. The Late Quaternary motions along the inverted structures was accommodated to the west by a major N-S oriented left-lateral fault zone, which separates the active contractional domains from the adjacent sectors of the African margin. As a whole, the Late Quaternary contractional tectonics of SE Sicily have been related to a NW-verging crustal stacking, related to a Mantle intrusion beneath the Hyblean Plateau that developed as effect of the rift flank deformation. The crustal lineaments, which compose the new kinematic model, represents potentially active seismogenic sources that might be considered in the frame of the seismotectonic picture of the Catania region.

Keywords: active tectonics, contractional structures, morphological responses, eastern Sicily, riftflank deformation and seismotectonics

\section{Introduction}

In the Catania region, in eastern Sicily (Fig. 1), several Authors (Labaume et al., 1990; Lanzafame et al., 1997; Monaco, 1997; Monaco et. al., 2002) have documented the growth of Middle Pleistocene (> $200 \mathrm{ka}$ ) contractional structures, along the southern margin of Mt. Etna 
Volcano, at the front of the Maghrebian Collision Belt (Fig. 1). More recent studies (Catalano et al., 2004; 2007) described the occurrence of younger ENE-WSW oriented folds that, coherently with the active NNW-SSE oriented Nubia-Eurasia convergence, deform alluvial terraces as young as the $40 \mathrm{ka}$. This younger fold system developed along the western flank of the roughly N-S oriented Siculo-Calabrian Rift Zone (SCRZ) (Monaco \& Tortorici, 2000; Catalano et al., 2008a), which consists of NNW-SSE trending major extensional faults located in the immediate Ionian off-shore area (Fig. 1). The seismological data (Neri et al., 2005) and stress-in-situ measurements along the western flank of the rift zone (Bousquet et al., 1988; Ragg et al., 1999) demonstrate the occurrence of a still active compressional regime, which is centred in the Mt. Etna region. This suggests that the growth of contractional structures can be still active and related to the seismicity of the Catania region. In this study, the geometry and the morphological evidence of the Late Quaternary contractional structures of the Catania region are analysed in order to define the displacement-rate and the mechanism of their evolution in the frame of the regional dynamics and seismotectonics of this densely populated area. The methodology includs morphometric analyses, applied on the Late Pleistocene alluvial terraces and the Holocene alluvial plain of the Simeto and Dittaino rivers (Catania Plain), and the study of channel morphology along the two main streams. The morphological data are augmented by surface geological information, derived from 1:10.000 scale field mapping, combined with the results of electrical resistivity tomography, performed across the Holocene alluvial plain.

\section{Regional setting}

Eastern Sicily is located along the Nubia-Eurasia convergent boundary (Dewey et al., 1989; Serpelloni et al., 2007), where the Neogene-Quaternary southeastern-verging Maghrebian Thrust Belt originated from the tectonic inversion of the former Africa continental palaeomargin (see inset

1 in Fig. 1). The geometry of the collision belt consists of two imbricated continental blocks 2 (Panormide and Pelagian blocks) and a thin-skinned Neogene-Quaternary accretionary wedge, 
which is sandwiched between them (Roure et al., 1990)(Fig. 2). A main E-W oriented, N-dipping crustal oblique (dextral) thrust (Mt. Kumeta-Alcantara Line of Ghisetti and Vezzani, 1982), which crops out in northern Sicily, represents the leading edge of the Panormide Block, also playing the role of back-stop of the Neogene-Quaternary accretionary wedge (Roure et al., 1990). This is emplaced on the Pelagian continental crust that, being buried beneath the entire eastern Sicily, culminates in the south-eastern sectors of the island, where it forms the Hyblean foreland domain (Ben Avraham et al., 1990). The present geometry of the Pelagian Block is the result of the Neogene-Quaternary flexure beneath the SE-verging orogenic belt. During Quaternary; this process was associated with the reactivaction of a main N-S oriented dextral transform fault zone, the Scicli Line (Grasso \& Reuther, 1988)(Fig. 1). To the west of this fault zone, the Hyblean Foreland sequences have also been flexured to form the Early Pleistocene NE-SW oriented Gela Foredeep (Grasso \& Reuther, 1988; Grasso et al., 2000). To the east of the Scicli Line, the Hyblean Foreland sequences form a wide plateau, bordered to the north by two Middle Pleistocene collapsed basins, the Scordia-Lentini Graben and the Simeto Graben (Fig. 1)(Ghisetti \& Vezzani, 1980) that are superimposed on the previous foredeep basin developed in the Catania region. Recent studies (Bousquet \& Lanzafame, 2004; Catalano et al., 2008b) have documented a Late Quaternary tectonic inversion along both the Scicli Line, from right- to left-lateral, and along the margins of the associated Scordia-Lentini Graben, from extensional to contractional. As a consequence, during the Late Quaternary, the eastern portions of the Hyblean Plateau have been displaced to the northwest, towards the Catania Plain, at a rate estimated to be about $1.4 \mathrm{~mm} / \mathrm{a}$ (Catalano et al., 2008b).

The entire collision belt of eastern Sicily is confined, to the east, by the Siculo-Calabrian Rift Zone (SCRZ) (Monaco \& Tortorici, 2000); this is the tectonic expression of an incipient divergent margin, which separates the Adria-Ionian microplate from the colliding Tyrrhenian and Pelagian lithospheric domains (Serpelloni et al., 2007) (Fig. 1). The rift zone, in the Catania area, is composed of NNW trending oblique (dextral) extensional faults that are distributed from the eastern flank of Mt.Etna to the Ionian off-shore of the Hyblean Plateau, (Monaco et al., 1997; Monaco \& 
Tortorici, 2000; Catalano et al., 2008a).

\section{Late Quaternary deformation and seismotectonics of Sicily}

Sicily has been affected by intense Late Quaternary deformation, associated with high-level seismicity, which can be related to distinct seismogenic domains (Neri et al., 2005). Low to medium magnitude events $(4<\mathrm{M}<6)$ affect the deformation belt, which is related to the Eurasia-Nubian convergent boundary (see inset $\mathbf{a}$ in Fig. 1). The seismicity is concentrated along the Tyrrhenian off-shore and the northwestern sectors of the island, where available focal mechanisms constrain a stress field characterised by a N130 ${ }^{\circ}$ oriented maximum compression. Similarly, focal mechanisms indicating motions along NE-SW oriented thrust fault have been reconstructed for the 1968 Belice seismic sequence (4.6 $\leq \mathrm{M} \leq 5.4$; Anderson \& Jackson, 1987; Monaco et al., 1996) that affected the external areas of the orogen, in the southwestern Sicily (see inset a in Fig. 1).

In eastern Sicily, the present-day stress field has a different orientation because the $\boldsymbol{\sigma}_{\mathrm{hmax}}$ follows the trend of the SCRZ, being NE-SW, in the Eolian Islands, and NNW-SSE, in the Mt. Etna region (Neri et al., 2005). A $\mathrm{N} 145^{\circ}$ oriented $\sigma_{1}$ has been obtained by the inversion of seismological data in the Hyblean region (Musumeci et al., 2005). This evidence is in good agreement with the focal mechanism of the 1990 Augusta earthquake (Amato et al., 1995), that indicates a NW-SE compression and a NE-SW tension (see inset a in Fig. 1).

Seismological data at a regional scale are consistent with the geodetic deformation that can be obtained by GPS-determined velocities with respect to stable Eurasia. Motions are constantly parallel to the maximum compression of the stress tensor. At sites LAMP and TRAP (see inset in Fig. 1; Hollestein et al., 2003) the measured NW-oriented GPS-velocities vs. Eurasia are parallel to the direction of the maximum compression measured in the western Sicily seismogenic domains. The slightly clockwise rotated NOTO vector (see inset $\mathbf{a}$ in Fig. 1) parallels the $\boldsymbol{\sigma}_{1}$ orientation in the Hyblean-Mt. Etna subdomain. It is noteworthy that the difference between NOTO and LAMP vectors is largely accommodated by the left-lateral motions along the Scicli Line (Catalano et al., 
2008b).

Geodetic deformation also indicates that about $2.6 \mathrm{~mm} / \mathrm{a}$ of shortening, representing the $63 \%$ of the entire NW-SE oriented Africa-Eurasia convergence, is accommodated by folding and thrusting within the Sicily collision belt (NOTO site vs. USTICA site; see inset a of Fig. 1), while the residual convergence $(1.5 \mathrm{~mm} / \mathrm{a})$ measured at Ustica site must be accommodated further to the north.

In-situ stress measurements also fit well the seismological and geodetic data, as they indicate mean $\boldsymbol{\sigma}_{\mathbf{h m a x}}$ orientation of about $\mathrm{N} 131^{\circ}$, in western Sicily, and $\mathrm{N} 148^{\circ}$ in the Hyblean foreland areas (Ragg et al., 1999).

Nevertheless, the main destructive (M> 6.5) historical earthquakes of Sicily (A.D. 1169, 1542, 1693) have been localised along the Ionian coast of the island (Postpischl, 1985; Boschi et al., 1995; 1997; Bianca et al., 1999; Monaco \& Tortorici, 2000). They define a major seismogenic zone which is related to the occurrence of the active normal fault segments of the SCRZ (Fig. 1). Available crustal focal mechanisms in the Straits of Messina area (Anderson \& Jackson, 1987; see inset a in Fig. 1), coupled with kinematic analyses on fault planes along the eastern flank of Mt.Etna (Monaco et al., 1997; Monaco \& Tortorici, 2000), indicate that motion along the normal fault belt occurred in response of a $\mathrm{N} 100^{\circ}$ oriented maximum extension. The analysis of seismic lines across the offshore active fault segments (Bianca et al., 1999) and morpho-structural investigations carried out along the on-shore fault planes (Monaco et al., 1997) suggested Late Quaternary average extensional-rates ranging from 1.7 to $3.7 \mathrm{~mm} / \mathrm{a}$. These data are in good agreement with GPS measurements carried out in southern Italy (Hollestein et al., 2003). In more detail, a mean active extension of about $3.5 \mathrm{~mm} / \mathrm{a}$ has been calculated in the Messina Straits Region (D'Agostino \& Selvaggi, 2004).

\section{Late Quaternary evolution of the Catania region}

The town of Catania is located on the northern margin of the NE-SW oriented Middle 
131 Pleistocene Simeto Graben (Fig. 1) that originated at the front of the Maghrebian Thrust Belt and is

132 filled by more than $1000 \mathrm{~m}$ of pelagic sediments (1.2 to 0.6 Ma-old; Di Stefano and Branca, 2002).

133 The seismic lines across the basin and bore-hole data (Torelli et al., 1998; Fig. 3) emphasize that the

134 Simeto Graben sequence seals the tectonic contact of the frontal nappe of the allochthonous edifice

135 (Gela Nappe) upon the Early Pleistocene horizons of the Catania Foredeep (P-Q in Fig. 3)(Lentini 136 and Vezzani; 1978; Bianchi et al., 1987; Lentini et al., 1996 and references therein), which are 137 located at the top of the flexured Hyblean carbonate sequences (Roure et al., 1990; Lentini et al., 138 1994)(Fig. 3). The southern margin of the Simeto Graben is represented by the Primosole Horst 139 (Fig. 3), where Middle Pleistocene extensional features are still preserved (Torelli et al., 1998). 140 Conversely, the northern border of the basin has been completely obliterated by younger (200 ka) 141 ramp-thrusts that bound the Dittaino-Simeto and the Terreforti highs (Monaco, 1997; Catalano et 142 al., 2004). Seismic lines across the deposits of the Simeto Graben image an incipient NW-ward gently dipping detachment that ramps from the base of the allochthonous units through the Middle Pleistocene horizons. This detachment has been recognised at a depth of about $2000 \mathrm{~m}$, beneath the

145 Catania Plain and it approaches the surface near the coast (Fig. 3; Torelli et al., 1998). The deposits 146 of the Simeto Graben are now covered by the alluvial plain of the Simeto and Dittaino Rivers 147 (Catania Plain).

The Simeto Graben sequence is extensively exposed in the hangingwall of the thrust bordering the basin to the north. Along the Terreforti High (Fig. 3), Late Quaternary clastic deposits engrave several orders of terraced abrasion platforms, which have been modelled at the top of the Middle

151 Pleistocene clay sequence. The terraced deposits represent regressive marine sequences $\left(\mathbf{S}_{\mathbf{1}}-\mathbf{S}_{\mathbf{7}}\right.$ in 152 Catalano et al, 2004), upward grading into alluvial conglomerates ( $\mathbf{T}_{\mathbf{1}}-\mathbf{T}_{\mathbf{7}}$ in Catalano et al, 2004; 153 see also Chester and Duncan, 1982; Monaco, 1997; Monaco et al., 2000)(Tab. 1), that were accumulated during successive periods of highstand, under the control of active tectonic uplift and deformation (Fig. 3). The fluvial terraces along the left side of the Simeto River (Chester and Duncan, 1982) can be, thus, interpreted as cyclic features, strictly related to the eustatically 
controlled marine sequences distributed along the coastal slope of the town of Catania. This implies that the age of the marine deposits can be extended also to the correlative alluvial deposits (Caputo et al., 2008).

The older terraced sequence ( $\mathbf{S}_{\mathbf{1}}$ and $\mathbf{T}_{\mathbf{1}}$ in Catalano et al, 2004)(Tab. 1) rests on an abrasion platform undercutting 320-250 ka-old subaerial subalkaline lavas (Gillot et al., 1994) and is intruded by 200 ka-old sub-volcanic rocks (Del Negro et al., 1998), while the youngest sequence $\left(\mathbf{S}_{7}\right.$ and $\mathbf{T}_{7}$ in Catalano et al, 2004)(Tab. 1) is largely covered by subaerial lava flows from the modern central volcano (<35 ka-old; Gillot et al., 1994). Taking into account the relation between eustacy and terracing, the age of the terraced sequences is thus constrained within the OISs (Oxygen Isotope Timescale Stages) to have occurred since $250 \mathrm{ka}$ B.P., as also demonstrated by occurrence of volcanic pebbles from the Etnean sub-alkaline lavas (320-250 ka old; Gillot et al., 1994) in the coarse grained levels (Monaco et al., 2002).

In more detail, the lowermost five terraced sedimentary wedges and the correlative alluvial terraces $\left(\mathbf{T}_{3}-\mathbf{T}_{7}\right.$ in Catalano et al, 2004) (Tab. 1) undercut the 180 ka-old alkaline volcanics and can be thus related to the five main highstands between the OIS 5.5 (125 ka) and 3.1 (40 ka)(Tab. 1). This indirect dating, based on geomorphic evidence, is also supported by the occurrence of volcanic pebbles from the ancient alkaline lavas in the coarse-grained levels (Monaco, 1997). This implies that the lowermost fluvial terrace $\left(\mathbf{T}_{7}\right.$; Tab. 1), flanking the courses of the Simeto and Dittaino Rivers, can be assigned to the OIS 3.1 (40 ka).

The Middle Pleistocene (240-200 ka) terraced deposits are severely deformed by the contractional structures developed by the positive tectonic inversion of the northern margin of the Simeto Graben as a result of the propagation of a dextral shear zone from the collision belt. These structures are mostly represented by E-W oriented ramp-thrusts associated with major NW-SE oriented dextral strike-slip fault zones (Fig. 3 and Tab. 1; Catalano et al., 2004). In contrast, the Upper Pleistocene deposits, ranging in age from 125 to $40 \mathrm{ka}$, have been severely uplifted, as a consequence of the deformation along the extensional faults of the SCRZ, located in the Ionian off- 
183

184

185

186

187

188

189

190

191

192

193

194

195

196

197

198

199

shore region (Tab. 1; Monaco et al., 2002; Catalano et al., 2004). During the last 40 ka, the syn-rift deformation has been accompanied by the propagation through the Catania Plain of a set of ENEWSW oriented gentle folds (Contrada Agnelleria, Contrada Rotondella and Sigonella anticlines in Fig. 3; Catalano et al., 2004), that has deformed the most recent alluvial terrace ( $\left.\mathbf{T}_{7} ; 40 \mathrm{ka}\right)$ (Tab. 1).

5. The most impressive contractional structure of the Catania region is represented by a N70 oriented, northwest-dipping ramp thrust. It involves terraced deposits as young as $80 \mathrm{ka}$ (Monaco et al., 2002), as observed in the southern sector of the town of Catania, in a quarry (Fig. 4). In this area, the alluvial conglomerates belonging to terrace $\mathbf{T}_{5}$ (OIS 5.1; Monaco et al., 2000) (Tab. 1) unconformably cover the 200 ka-old marine sandy sequence $\left(\mathbf{S}_{2}\right)$ (see inset a of Fig. 4), which is severely tilted towards the south, at the eastern termination of the Terreforti High (Fig. 3; Catalano et al., 2004). The syn-rift thrust-ramp is responsible for the local overthrusting of the marine terraced sequence $\left(\mathbf{S}_{\mathbf{2}} ; 200 \mathrm{ka}\right)$ onto the alluvial conglomerates of the $\mathbf{T}_{\mathbf{5}}(80 \mathrm{ka})$ (see inset $\mathbf{b}$ of Fig. 4). The total vertical displacement along the structure has been estimated at about $10 \mathrm{~m}$, considering the off-set of the 80 ka-old unconformity across the ramp. In the hanging-wall of the structure, the motion along the ramp has produced the propagation of a fan of minor slip planes that isolate a $\mathrm{N70}{ }^{\circ}$ oriented kink band, which has further tilted the S-dipping strata (Fig. 4).

The described thrust-ramp developed at the forelimb of the N70 oriented Sigonella Anticline (Fig. 3), a wide box-fold that extends towards the SW, as far as $13 \mathrm{~km}$ from the urban area of Catania. The anticline is well exposed in the area of the village of San Giorgio, on the northern margin of the Catania Plain, where it deforms 60 ka-old terraced alluvials ( $\mathbf{T}_{\mathbf{6}}$ in Catalano et al., 2004) (Tab. 1) as well as several older (125 to $80 \mathrm{ka})$ marine terraced deposits $\left(\mathbf{S}_{\mathbf{3}}-\mathbf{S}_{\mathbf{5}}\right.$ in Catalano et al., 2004) (Tab. 1). The marine strandline of the OIS $5.5(125 \mathrm{ka})$ is involved in the inner flank of the box-fold, along which is regularly increasing in elevation from 120 to $150 \mathrm{~m}$ a.s.1.. The $100 \mathrm{ka}-$ old (OIS 5.3) marine strandline crosses the crest of the structure, showing a change in elevation from about $80 \mathrm{~m}$ a.s.1., at the base of the inner flank, to $120 \mathrm{~m}$ a.s.1., at the crest of the anticline. The 
younger marine strandlines, as well as the $60 \mathrm{ka}$-old alluvial deposits, are confined to the forelimb of the anticline, being deformed as far as $2 \mathrm{~km}$ from the crest of the structure. The morphological features of different ages that are involved in the structure, as a whole, suggest a wavelength of the fold of about $4 \mathrm{~km}$ with an estimated amplitude of about $40 \mathrm{~m}$.

Towards the southwest, the crest of the anticline has been buried by the Holocene deposits of the Catania Plain. The stratigraphy of the uppermost $60 \mathrm{~m}$ thick levels of the alluvial plain have been investigated, by a series of electrical resistivity surveys, across the southwestern prolongation of the Sigonella Anticline, near the confluence between the Simeto and Dittaino rivers. North and south of the structure (cross-sections 1 and 3 in Fig. 5), the reconstructed resistivity pseudocrosssections have imaged three well defined superimposed electrostratigraphical units, each corresponding to as many sedimentary units: the shallower $15-25 \mathrm{~m}$ thick level $(\mathrm{R}=8-4 \mathrm{Ohm} \cdot \mathrm{m})$ is represented by the Holocene alluvial sands and conglomerates, the intermediate $35 \mathrm{~m}$ thick level $(\mathrm{R}=10-30 \mathrm{Ohm} \cdot \mathrm{m})$ corresponds to the Late Pleistocene sands and conglomerates $\left(\mathbf{T}_{7} ; 40 \mathrm{ka}\right)$, while the deeper very low-resistivity $(\mathrm{R}<4 \mathrm{Ohm} \cdot \mathrm{m})$ layer corresponds to the top of the Middle Pleistocene marly-clay levels of the Simeto Graben. The tomographic model to the north of the fold crest (profile 1 in Fig. 5) shows a slight $\mathrm{N}$-ward tilting of the layering, with the consequent $\mathrm{S}$-ward narrowing of the Holocene alluvial deposits from 25 to $15 \mathrm{~m}$, on a distance of about $300 \mathrm{~m}$ $\left(\operatorname{dip}=2^{\circ}\right)$. The tomographic model crossing the buried crest of the Sigonella Anticline (profile 2 in Fig. 5) reveals a further narrowing $(<5 \mathrm{~m})$ of the Holocene alluvial deposits. In the resistivity pseudo cross-section, the forelimb of the fold is also marked by the occurrence, at depth, of a NEdipping body that, characterised by higher resistivity values (20 to $35 \mathrm{Ohm} \cdot \mathrm{m}$ ), cutting at high angle the sub-horizontal layering. The geometry of this resistivity anomaly is consistent with the occurrence, as well as in the Catania area, of heavy fractured fault-rocks, associated with a NEdipping thrust-ramp. As similar to the Catania town section, the tomographic model across the structure suggests a very small vertical displacement that can be estimated at about $10 \mathrm{~m}$, if 
measured on the offset of the base of the sandy levels, while it is reduced to about $5 \mathrm{~m}$, considering only the offset of the base of the Holocene alluvial deposits.

In the northwestern sector of the Catania Plain and in the adjacent Terreforti High, further two Late Quaternary N70 oriented anticlines (Contrada Rotondella and Contrada Agnelleria anticlines of Catalano et al., 2004) can be recognised (Fig. 3). These two gentle folds show very low amplitude (20 and $40 \mathrm{~m}$ ) and long wavelength ( 3 to $4 \mathrm{~km}$, respectively). The Contrada Agnelleria and Contrada Rotondella folds appear as slight flexures of the top-surface of the youngest terraced alluvial deposits ( $\mathbf{T}_{7} ; 40 \mathrm{ka}$ ) (Tab. 1), showing interlimb angles that approximate the $180^{\circ}$ (Fig. 6). The geometry of these folds shows almost uniform amplitude and length on surface of different age, where they deform the older terraced alluvial deposits $\left(\mathbf{T}_{\mathbf{1}}-\mathbf{T}_{\mathbf{6}} ;\right.$ Tab. 1). The morphology of the folds is completely absent in the Holocene floodplain, which shows a very low-gradient $(0,3 \%)$ longitudinal profile, almost parallel to that of the active channel of the Simeto River.

Out of the folded area, the $\mathbf{T}_{7}$ terrace (Tab. 1) is regularly dipping, at very low-angle $\left(0.34^{\circ}\right)$, towards the Ionian sea. In contrast, in the folded area, the $\mathbf{T}_{7}$ terrace shows evident undulations, as it culminates to form ENE-WSW elongated ridges, corresponding with the well-rounded hinge zones of the anticlines, which are separated by wide $U$ shaped topographic depressions that have developed where the terraced surfaces have been subsided at the core of the synclines (Fig. 6). Approaching the crest of the Contrada Agnelleria and Contrada Rotondella anticlines, the $\mathbf{T}_{7}$ terrace (Tab. 1) shows a slight divergence $\left(1.34^{\circ}\right)$ from the alluvial plain, coupled with convergence $\left(0.40^{\circ}\right)$ towards the intermediate synclines. The steeper and shorter NNW-dipping limbs suggest a NNW vergence of the folds. To the southeast of the Rotondella anticline, the 40 ka-old fluvial deposits have been covered by the Holocene deposits of the Catania Plain.

The syn-rift contractional deformation has also controlled the evolution of the Holocene fluvial morphology of the Catania Plain, which formed by the merging of the Simeto and Dittaino river floodplains (Fig. 3). The final tract of the Simeto River is characterised by an arcuated meandering course that, varying in direction from the N-S to the NW-SE, crosses at high-angle the 
Late Quaternary anticlines of the Catania region (Fig. 3). At a distance of about $25 \mathrm{~km}$ from the

261 mouth, the active channel of the Simeto River as well as the top of the Holocene floodplain show a very low-gradient (about $0.3 \%$ ), crossing undisturbed the folds that deform the 40 ka-old alluvial terrace $\left(\mathbf{T}_{7}\right)$.

In the Catania Plain, a very impressive change in the sinuosity index $(\mathbf{S})$ of the river channel occurs at the intersection with the Sigonella Anticline (from the reach 6 to 7; Fig. 7). This variation, even if partly obliterated by modification due to the human activities, has been estimated taking into account the topographic data from the 1867 1:50.000 topographic map, the 1:100.000 topography reported in the geological map of the end of the XIX century (Gemmellaro and Travaglia, 1885; Gemmellaro et al., 1885) and, finally, the 1960 edition of I.G.M.I. 1:25.000 topographic map. If measured on the XIX century topography, the variation of the sinuosity can be estimated from 1.75 to 3.75. A reduced change of the sinuosity (from 1.75 to 2.5 ) is imaged in the 1960 topography, as a consequence of the cut-offs of meanders that occurred in the last century.

To the west of the Simeto River, the Dittaino River is characterised by a prevalent NW-SE oriented meandering course, which flows from the external areas of the Maghrebian Orogen to the Catania Plain, crossing roughly perpendicular the NE-SW oriented termination of the Scicli Line. At the intersection with the structure, which is located between the reach 2 and the reach 3 (Fig. 7), the Dittaino River shows an evident increase of the sinuosity, of about the $100 \%$ (from 1.5 to 3 ), that was attenuated at about $60 \%$, due to the cut-off of meandersin the reach 3 during the last century. From the Scicli Line to the mouth, the sinuosity of the river remains almost uniform and constant in the time. Nevertheless, the Dittaino displays a large scale deflection, which bounds the 281 western terminations of the Rotondella and Sigonella anticlines, as it enters in the Catania Plain (Fig. 7). 


\section{Discussion and conclusions}

A Late Quaternary fold and thrust system that developed along the flank of an active rift zone in the Catania region has been described. The Late Quaternary contractional structures as a whole generate a triangle zone, involving the Lower-Middle Pleistocene deposits of a former extensional basin (Simeto Graben) and deforming Upper Pleistocene and Holocene morphological features (Fig. 3). The south-verging active boundary of the triangle zone is represented by the ramp-thrust outcropping in the town of Catania, here referred to as Catania-Sigonella Thrust (CST), responsible for adjustments in the fluvial morphology along the Simeto River. At the intersection between the river and the structure, a dramatic change in the sinuosity is documented by several historical topographic maps (Fig. 8). The synoptic analysis of the 1:50.000 scale topographic map, edited in the 1867 , of the topography reported in the 1:100.000 scale geological map of the end of the XIX century (Gemmellaro and Travaglia, 1885; Gemmellaro et al., 1885) and of I.G.M.I. 1:25.000 topographic map, edited in 1960, demonstrates that the difference in the sinuosity, between reaches 6 and 7 (Fig. 8), has in about 100 yrs progressively decreased from 2 to 0.75 . The CST accumulated a total vertical displacement of about $10 \mathrm{~m}$, half of which is related to Holocene motions as suggested by the clear control on the fluvial morphology. This implies that the structures developed in the last $20 \mathrm{ka}$, with an averaged vertical displacement-rate of about $0,5 \mathrm{~mm} / \mathrm{a}$.

The opposite north-verging tectonic boundary of the active triangle zone can be located along the northern limb of the Agnelleria Fold, on the prolongation of the active NE-SW oriented splay of the Scicli Line, here designated as the Sferro-Paternò Thrust (SPT), displacement on which has caused the morphological responses recognised along the Dittaino River. The intersection between the river and the structure is also in this case marked by a well defined change in sinuosity, only partially attenuated in the last century. The recognised responses of the fluvial morphology, which have been modelled in the literature by Holbrook \& Schumm (1999), document very recent longitudinal tilting of the active channels of the Simeto and Dittaino Rivers, at the intersection with 
311 the two tectonic boundaries of the triangle zone and, thus, directly related to recent motion along the

312 SPT and the CST.

313 Conversely, the undeformed Holocene morphological features, which are incised into the

314 entire fold belt, and the geometry of the Late Pleistocene fluvial terraces suggest that the folding is 315 restricted to the time interval from 40 to $10 \mathrm{ka}$. Considering the evolution of these contractional 316 structures, the Late Pleistocene anticlines can be interpreted as fault-propagation folds affected by 317 opposite vergences, that deactivated when the thrusts reached the surface. Thereafter, the entire 318 triangle zone was uplifted, confined to the west by the large scale deflection of the Dittaino River.

319 The cumulative shortening across the entire triangle zone can be estimated taking into account 320 the vertical displacement of the Late Quaternary terraces and the shortening due to the gentle 321 folding $(<3 \mathrm{~m})$. The terracing of the $40 \mathrm{ka}$-old fluvial deposits is confined at the hangingwall of the 322 SPT. These old alluvial sediments were deposited during OIS 3.1, when the base level was about 40 323 m lower than Present (Bassinot et al., 1994). Considering an average elevation of the terrace of 324 about $30 \mathrm{~m}$ above the modern Simeto River, a cumulative uplift of about $70 \mathrm{~m}$ is implied. A large 325 portion of this uplift can be related to the regional signal that has been estimated to be about 0.8 $326 \mathrm{~mm} / \mathrm{a}$ (Catalano et al., 2004). The residual amount of uplift (38 m) can be interpreted as the tectonic 327 contribution of the SPT. Considering that the reverse faulting developed along a former extensional 328 margin, a dip of $60^{\circ}$ for the inverted fault-plane can be tentatively assumed. This would imply a 329 conversion of the vertical motion into a shortening of about $22 \mathrm{~m}$. Taking also into account the 330 motion along the CST and the gentle fold deformation, a shortening of about $35 \mathrm{~m}$ has been 331 accommodated by the entire triangle zone in the last $40 \mathrm{ka}$, at a deformation-rate of about $0.8-0.9$ $332 \mathrm{~mm} / \mathrm{a}$. A rough estimate of the depth of the sole-thrust of the triangle zone can be obtained 333 comparing the amount of the relief produced at the surface by the Late Quaternary thrust motion 334 with the related cumulative shortening. Assuming plane-strain deformation, a depth of the sole335 thrust of about $7500 \mathrm{~m}$ is obtained by analysing the deformation of the 40 ka-old alluvial terrace $336\left(\mathbf{T}_{7}\right)$ along the topographic profiles, drawn perpendicular to the trend of the contractional structures 
(Fig. 6). This implies, considering a depth of about $2000 \mathrm{~m}$ of the sole-thrust of the allochthonous units beneath the Catania Plain ( $\mathbf{T}_{\mathbf{1}}$ in Fig. 3), that the relation between the Late Quaternary deformation of the triangle zone and the migration of the front of the orogen is unrealistic.

The geometry, the estimated depth of the basal detachment and the deformation-rate of the triangle zone are, however consistent with the Late Quaternary contractional deformation affecting the Hyblean crustal block, which is bounded to the west by the Scicli Line. In this region, the Early Pleistocene extensional features (e.g. Scordia-Lentini Graben) experienced a diffuse Late Quaternary positive tectonic inversion, associated with the inversion of the sense of motion along the Scicli Line (Catalano et al., 2008b). The authors have constrained the positive tectonic inversion of the Scordia-Lentini Graben, connected to the left-lateral motion along the southernmost segments of the Scicli Line, at about $850 \mathrm{ka}$. Recent studies (Catalano et al., 2010) have interpreted the inversion tectonics as related to a rift-flank deformation, affecting the eastern sectors of the Hyblean Plateau, located at the footwall of the SCRZ. The authors have related the surface inverted tectonics of the southern margin of the Scordia-Lentini Graben to the emergence of a NNW-verging crustal ramp that originated from a Mantle intrusion, which has been inferred at a depth of about $25 \mathrm{~km}$.

It is worth noting that the described surface inverted structures have accommodated only a small amount $(30 \%)$ of the sinistral strike-slip motion along the Scicli Line, thus suggesting that part of the contraction should be taken up along blind structures, located more to the north. The present study suggests that a NNW-ward propagation of the inverted contractional structures may have migrated for about $30 \mathrm{~km}$ in the last $850 \mathrm{ka}$ (Fig. 8). The overall surface geometry of these younger inverted structures is compatible with a detachment, located at depth of about $7500 \mathrm{~m}$, along the Permo-Triassic levels at the base of the sedimentary succession of the Hyblean Plateau (Bianchi et al., 1987), that ramps to form the SPT, since about $40 \mathrm{ka}$. In this context, the CST, which forms the opposite boundary of the triangle zone would represent a secondary back-thrust, characterised by a very low cumulative displacement. The measured shortening-rate $(0.8-0.9 \mathrm{~mm} / \mathrm{a})$ along the inverted triangle zone of the Catania Plain is comparable with the residual left-lateral 
363 deformation-rate $(\approx 1 \mathrm{~mm} / \mathrm{a})$, affecting the northernmost segments of the Scicli Line, to the north of 364 the Scordia-Lentini Graben. According to this new kinematic model, the active contractional 365 deformation of the Catania region can be related to the dynamics affecting the whole of 366 southeastern Sicily, driven by mantle intrusion triggered by the rift-flank deformation along the 367 SCRZ, rather than to the late evolution of the collision belt (Catalano et al., 2010).

This new kinematic and dynamic model has consequences for the regional seismotectonic 369 picture, if the contractional deformation of the Catania region is to be related to motion along the northern segments of the Scicli Line and the southern inverted margins of the Scordia-Lentini Graben. These tectonic alignments represent major crustal structures that must be considered as potential seismogenic sources for locating historical earthquakes. As well, the measured deformation rates are significant and should be accounted for when evaluating the recurrence-time of seismicity in the area.

\section{References}

Amato, A., Azzara, R., Basili, A., Chiarabba, C., Cocco, M., Di Bona, M., Selvaggi, G., 1995. Main shock and aftershocks of the December 13, 1990, Eastern Sicily earthquake. Ann. Geofis. 38

Anderson, H., Jackson, J.A., 1987. Active tectonics in the Adriatic region. Geophis. J. R. Astron. Soc. 91, 937-983.

Bassinot, F.C., Labeyrie, L.D., Vincent, E., Quidelleur, X., Shackleton, N.J., Lancelot, Y., 1994. The astronomical theory of climate and the age of the Brunhes-Matuyama magnetic reversal. Earth Planet. Sci. Lett., 126, 91-108.

Ben Avraham, Z., Boccaletti, M., Cello, G., Grasso, M., Lentini, F., Torelli, L., Tortorici, L., 1990. 
Bianca, M., Monaco, C., Tortorici, L., Cernobori, L., 1999. Quaternary normal faulting in southeastern Sicily (Italy): A seismic source for the 1693 large earthquake. Geophys. J. Int. $139,370-394$.

Bianchi, F., Carbone, S., Grasso, M., Invernizzi, G., Lentini, F., Longaretti, G., Merlini, S., Mostardini, F., 1987. Sicilia orientale: Profilo geologico Nebrodi-Iblei. Mem. Soc. Geol. Ital. $38,429-458$.

Boschi, E., Ferrari, G., Gasperini, P., Guidoboni, E., Smeriglio, G., Valensise, G., 1995. Catalogo dei forti terremoti in Italia dal 461 a.c. al 1980. Istituto Nazionale di Geofisica, S.G.A., Roma.

Boschi, E., Guidoboni, E., Ferrari, G., Valensise, G., Gasperini, P., 1997. Catalogo dei forti terremoti in Italia dal 461 a.c. al 1990. Istituto Nazionale di Geofisica, S.G.A., Roma.

Bousquet, J.C., Lanzafame, G., Paquin, C., 1988. Tectonic stresses and volcanism: in-situ stress measurements and neotectonic investigations in the Etna area (Italy). Tectonophysics 149, 219-231.

Bousquet, J.C., Lanzafame, G., 2004. Compression and Quaternary tectonic inversion on the Northern edge of the Hyblean Mountains, foreland of the Appenine-Maghrebian chain in Eastern Sicily (Italy): geodynamic implications for Mt. Etna. GeoActa 3, 165-177.

Caputo, R., Salviulo, L., Bianca, M., 2008. Late Quaternary activity of the Scorciabuoi Fault (southern Italy) as inferred from morphotectonic investigations and numerical modeling. Tectonics 27, TC3004 doi:10.1029/2007TC002203

Catalano, S., De Guidi, G., Monaco, C., Tortorici, G., Tortorici, L., 2008a. Active faulting and seismicity along the Siculo-Calabrian rift zone. Tectonophysics 453, 177-192.

Catalano, S., De Guidi, G., Romagnoli, G., Torrisi, S., Tortorici, G., Tortorici, L., 2008b. The migration of plate boundaries in SE Sicily: influence on the large-scale kinematic model of the African Promontory in Southern Italy. Tectonophysics 449, 41-62.

Catalano, S., Romagnoli, G., Tortorici, G., 2010. Rift-flank deformation in SE Sicily: evidence for an active Mantle upwelling. Tectonophysics 486, 1-14. 
415 Catalano, S., Torrisi, S., De Guidi, G., Grasso, G., Lanzafame, G., Romagnoli, G., Tortorici, G., Tortorici, L., 2007. Sistema a pieghe tardo-quaternarie nell'area di Catania: un esempio di fronte orogenico attivo. Rend. Soc. Geol. It. 4 (2007), Nuova serie, 181-183. GIGS Urbino 12-13 marzo 2007.

Catalano, S., Torrisi, S., Ferito, C., 2004. The relationship between Late Quaternary deformation and volcanism of Mt. Etna (eastern Sicily): new evidence from the sedimentary substratum in the Catania region. J. Volcanol. Geotherm. Res. 132, 311-334.

Chester, D.K., Duncan, A.M., 1982. The interaction of volcanic activity in Quaternary times upon the evolution of the Alcantara and Simeto rivers, Mt. Etna, Sicily. Catena 9, 319-342.

D'agostino, N., Selvaggi, G., 2004. Crustal motion along the Eurasia-Nubia plate boundary in the Calabrian arc and Sicily and active extension in the Messina Straits from GPS measurements.

Del Negro, C., Lanzafame, G., Napoli, R., Pompilio, M., 1998. The age of the neck of Motta Sant'Anastasia (Sicily) as revealed by a magnetic survey. Acta Vulcanol. 10, 39-46.

Dewey, J.F., Helman, M.L., Turco, E., Hutton, D.H.W., Knott, S.D., 1989. Kinematics of the western Mediterranean. Alpine Tectonics, Geol. Soc. Spec. Publ. 45, 265-283.

Di Stefano, A., Branca, S., 2002. Long-term uplift rate of the volcano basement (southern Italy) based on biochronological data from Pleistocene sediments. Terra Nova 14, 61-68.

Gemmellaro, G.G., Mazzetti, L., Travaglia, R., 1885. Carta Geologica d'Italia Fº 269 I.G.M, "Paterno" (Isola di Sicilia). Sc. 1:100.000. R.Stab.Lit.e Cartogr.C. Virano, Roma.

Gemmellaro, G.G., Travaglia, R., 1885. Carta Geologica d'Italia F. 270 I.G.M, “Catania” (Isola di Sicilia). Sc. 1:100.000. R.Stab.Lit.e Cartogr.C. Virano, Roma.

Ghisetti, F., Vezzani, L., 1980. The structural features of the Hyblean Plateau and the Mount Judica area (South-Eastern Sicily): a microtectonic contribution to the deformational history of the Calabrian Arc. Boll. Soc. Geol. It. 99, 55-102. 
440 Ghisetti, F., Vezzani, L., 1982. Different styles of deformation in the Calabrian Arc (Southern 441 Italy); implication for a sismotectonics zoning. Tectonophysics 85, 149-165.

442 Gillot, P.Y., Kieffer, G., Romano, R., 1994. The evolution of Mount Etna in the light of potassium$443 \quad$ argon dating. Acta Vulcanol. 5, 81-87.

444 Grasso, M., Philps, B., Reuther, C.D., Garofalo, P., Stamilla, R., Anfuso, G., Donzella, G., Cultrone, G., 2000. Pliocene-Pleistocene tectonics on western margin of the Hyblean plateau

Grasso, M., Reuther, C.D., 1988. The western margin of the Hyblean Plateau: a neotectonic transform system on the SE Sicilian foreland. Annales Tectonicæ 2 (2), 107-120.

Holbrook, J., Schumm, S.A., 1999. Geomorphic and sedimentary of rivers to tectonic deformation : a brief review and critique of a tool for recognizing subtle epeirogenic deformation in modern and ancient setting. Tectonophisics 305, 287-306.

Hollenstein, Ch., Kahle, H.-G., Geiger, A., Jenny, S., Geos, S., Giardini, D., 2003. New GPS constraints on the Africa-Europe plate boundary zone in southern Italy. Geophys. Res. Lett. 30 (18), 1935, doi:10.1029/2003GL017554.

Labaume, P., Bousquet, J.C., Lanzafame, G., 1990. Early deformation at a submarine compressive front: The Quaternary Catania foredeep south of Mt. Etna, Sicily, Italy. Tectonophysics 177, 349-366.

Lanzafame, G., Neri, M., Coltelli, M., Lodato, L., Rust, D., 1997. North-South compression in the Mt. Etna region (Sicily) spatial and temporal distribution. Acta Vulcanol. 9, 121-133. 141-144.

Lentini, F., Carbone, S., Catalano, S., Grasso, M., 1995. Principali lineamenti strutturali della Sicilia nord-orientale. Studi Geologici Camerti, special issue 1995/2, 319-329. 
Lentini, F., Carbone, S., Catalano, S., Grasso, M., 1996. Elementi per la ricostruzione del quadro strutturale della Sicilia orientale. Mem. Soc. Geol. Ital. 51, 179-195.

Lentini, F., Vezzani, L., 1978. Tentativo di elaborazione di uno schema strutturale della Sicilia Orientale. Mem. Soc. Geol. Ital. 19, 495-500.

Monaco, C., 1997. Tettonica pleistocenica nell'area a sud dell'Etna (Sicilia orientale). Il Quaternario 10, 393-398.

Monaco, C., Bianca, M., Catalano, S., De Guidi, G., Tortorici, L., 2002. Sudden change in the Late Quaternary tectonic regime in eastern Sicily: Evidences from geological and geomorphological features. Boll. Soc. Geol. Ital. vol. spec. 1, 901-913.

Monaco, C., Catalano, S., De Guidi, G., Gresta, S., Langer, H., Tortorici, L., 2000. The geological map of the urban area of Catania (Eastern Sicily): Morphotectonic and seismotectonic implication. Mem. Soc. Geol. Ital. 55, 425-438.

Monaco, C., Mazzoli, S., Tortorici, L., 1996. Active thrust tectonics in western Sicily (Southern Italy): the 1968 Belice earthquake sequence. Terra Nova 8, 372-381.

Monaco, C., Tapponnier, P., Tortorici, L., Gillot, P.Y., 1997. Late Quaternary slip rates on the Acireale-Piedimonte normal faults and tectonic origin of Mt. Etna (Sicily). Earth Planet. Sci. Lett. 147, 125-139.

Monaco, C., Tortorici, L., 2000. Active faultingin the Calabrian arc and eastern Sicily. J. Geodyn. $29,407-424$.

Musumeci, C., Patanè, D., Scarfì, L., Gresta, S., 2005. Stress Directions and Shear-Wave Anisotropy: Observations from Local Earthquakes in Southeastern Sicily, Italy. Bull. Seism. Soc. Amer. 95 (4), 1359-1374.

Neri, G., Barberi, G., Oliva, G., Orecchio, B., 2005. Spatial variation of seismogenic stress orientations in Sicily, south Italy. Phys. Earth Planet. Interiors 148, 175-191.

Postpischl, D., 1985. Catalogo dei terremoti italiani dall'anno 1000 al 1980. CNR, P.F. Geodinamica, Graficoop Bologna. 
Ragg, S., Grasso, M., Muller, B., 1999. Patterns of tectonic stress in Sicily from borehole breakout observations and finite element modelling. Tectonics 18, 669-685.

Roure, F., Howel, D.G., Muller, C., Moretti, I., 1990. Late Cenozoic subduction complex of Sicily. J. Struct. Geol. 12, 259-266.

Serpelloni, E., Vannucci, G., Pondrelli, S., Argnani, A., Casula, G., Anzidei, M., Baldi, P., Gasperini, I., 2007. Kinematics of the Western Africa-Eurasia plate boundary from focal mechanisms and GPS data. Geophys. J. Int., doi10.111/J.1365-246X.2007.03367.x, 1-20.

Torelli, L., Grasso, M., Mazzoldi, G., Peis, D., 1998. Plio-Quaternary tectonic evolution and structure of the Catania foredeep, the northern Hyblean Plateau and the Ionian shelf (SE Sicily). Tectonophysics 298, 209-221.

\section{Figure captions}

Fig. 1: Geological sketch map of the Catania region, eastern Sicily.

Key: (1) Holocene deposits (a) Late Würmian-Holocene alluvial fan (b); (2) Etnean Lavas: recent alkaline products (80 ka to Present) (a); ancient alkaline products (180-100 ka) (b) (chronological data from Gillot et al., 1994); (3) sub-alkaline products of Mt. Etna volcanic district (320-200 ka) (chronological data from Gillot et al., 1994); (4) Middle Pleistocene deposits of the Simeto and Scordia-Lentini Graben and Late Quaternary marine terraces; (5) Early-Middle Pleistocene deposits of the Gela Foredeep; (6) Undifferentiated Meso-Cenozoic Maghrebian allochthonous units; (7) Pliocene-Early Pleistocene volcanics of the Hyblean Plateau; (8) Meso-Cenozoic foreland sequences of the western Hyblean Plateau; (9) Meso-Cenozoic foreland sequences of the eastern Hyblean Plateau; (10) buried front of the Maghrebian allochthonous units; (11) Pliocene- Early Pleistocene fault; (12) Middle Pleistocene extensional fault (Simeto and Scordia-Lentini Graben); (13) Late Quaternary and active tectonics and volcano-tectonics: strike-slip fault (a); normal fault of the "Siculo-Calabrian Rift Zone" (b), thrust (c), anticline (d) dry and eruptive fissure (e); (14) main transform fault zone; (15) maximum horizontal extension in the Etnean area and in the Ionian 
517 offshore; (16) maximum horizontal compression in the Catania Plain area; (17) main earthquake 518 (a): in the map the major $(M \geq 7)$ historical earthquakes are reported; the inset also shows the main 519 instrumental events, with available focal mechanisms (b)(the location of epicentres are from 520 Postpischl, 1985; Boschi et al., 1995 and 1997; Bianca et al., 1999; Monaco \& Tortorici, 2000; 521 Focal mechanisms are from Anderson \& Jackson, 1987; Amato et al., 1995; Pondrelli et al., 2002; 522 2004); (18) GPS vector; (19) rift-flank volcanoes (see in the inset a).

523 The inset a shows the deformation belts connected to the active Nubia-Eurasia convergent boundary and the SCRZ respectively. The inset $\mathbf{b}$ refers to the relative motion between the plates.

Fig. 2: Schematic geological profile across the eastern portion of the Sicily collision belt.

527 (for the location see inset $\mathbf{a}$ in Fig. 1)

Fig. 3: Geological map of the Simeto Graben (for location see box in Fig. 1). Note that the southern border of the collapsed basin (Primosole Horst) still shows the original (Middle Pleistocene) extensional features, while the northern margin (Dittaino-Simeto Horst) has been completely replaced by the Late Pleistocene contractional structures of the Terreforti High. In addition, within the basin Recent ( $<40 \mathrm{ka}$ ) to active ENE-WSW oriented folds and thrusts developed. Key: (1) Holocene alluvial deposits; (2) Recent etnean lava flows (< $80 \mathrm{ka}$ ); (3) 40-ka old alluvial terraced deposits; (4) Middle-Late Pleistocene alluvial terraces; (5) Middle Pleistocene marine terraced sequences; (6) Ancient alkaline lavas (180-100 ka); (7) sub-alkaline lavas (320-200 ka); (8)

537 Middle Pleistocene deposits of the Simeto Graben (1,2-0,6 Ma); (9) allochthonous units; (10) 538 Pliocene-Early Pleistocene volcanics of the Hyblean Plateau; (11) Carbonate foreland sequence of 539 the Hyblean Plateau; (12) Late Quaternary tectonics: (a) normal fault, (b) strike-slip fault, (c) thrust; 540 (13) Recent and active anticline (a), inverted reverse fault (b).

541 Dashed boxes in the figure refer to the location of Fig. 5 and Fig. 6, respectively. 
The stereoplots (Schmidt net, lower hemisphere projection) in the inset refers to measured

543 bedding of marine terraces of the following Oxygen Isotope Stages (OISs): a) OIS 7 (240-200 ka); b) OIS 5.5 (125 ka); c) OIS 5.3 (100 ka); d) OIS 5.1 (80 ka); e) OIS 3.3 (60 ka); f) OIS 3.1 (40 ka). In the geological profiles, which has been drawn on the basis of surface data, supported by bore-hole logs and seismic lines (Torelli et al., 1998), the tectonics related to distinct deformation stages are reported: $\mathbf{T}_{\mathbf{1}}$ ) sole thrust of the allochthonous nappe; $\left.\mathbf{T}_{\mathbf{2}}\right)$ Middle Pleistocene (> $\left.850 \mathrm{ka}\right)$ normal faults of the Simeto Graben; $\mathbf{T}_{\mathbf{3}}$ ) Middle Pleistocene (600-200 ka) ramp thrust; $\mathbf{T}_{\mathbf{4}}$ ) reactivated portion of $\mathbf{T}_{\mathbf{1}}(<40 \mathrm{ka})$.

Fig. 4: Photo showing the Late Quaternary $(<80 \mathrm{ka})$ thrust ramp $($ CST) exposed in the Catania Town. For details on the involved deposits, see the schemes $\mathbf{a}$ and $\mathbf{b}$ in the inset.

Fig. 5: Geoelectric tomographies in the Catania Plain, across the southwestern prolongation of the Sigonella Anticline. For location of the area see dashed box in Fig. 3. For locating the resistivity pseudocross-sections with regards to the investigated tectonics, see the inset.

Fig. 6: Digital elevation model (DEM) of the topography across the Sigonella, Rotondella and Agnelleria anticlines. In the model, the $40 \mathrm{ka}$-old alluvial terrace is evidenced. The cross-sections evidence the geometry of the surface at the top of the alluvial terrace (dashed grey line) compared with the reconstructed longitudinal profiles of modern rivers (dashed black line).

Fig. 7: Evolution of the sinuosity along the Simeto and the Dittaino rivers, across the Late Quaternary tectonics of the Catania Plain.

In the diagrams, the variation of sinuosity within successive reaches of the Simeto and the Dittaino rivers has been plotted, with reference to the 1867 and 1960 topographic maps, respectively. 
568 Fig. 8: Evolution of the Late Quaternary positive tectonic inversion at the flank of the SCRZ, in the 569 Catania region.

570

571 Tab. 1: Chronostratigraphic scheme of Upper and Middle Quaternary terraced sequences of the 572 northern margin of the Simeto Graben. For each sequence, the correlative OIS and the age are 573 reported. 
sequence

$\begin{array}{lll}\left(\mathrm{S}_{1}\right)\left(\mathrm{T}_{1}\right) & 7.5 & 240 \\ \left(\mathrm{~S}_{2}\right)\left(\mathrm{T}_{2}\right) & 7.1 & 200 \\ \left(\mathrm{~S}_{3}\right)\left(\mathrm{T}_{3}\right) & 5.5 & 125 \\ \left(\mathrm{~S}_{4}\right)\left(\mathrm{T}_{4}\right) & 5.3 & 100 \\ \left(\mathrm{~S}_{5}\right)\left(\mathrm{T}_{5}\right) & 5.1 & 80 \\ \left(\mathrm{~S}_{6}\right)\left(\mathrm{T}_{6}\right) & 3.3 & 60 \\ \left(\mathrm{~S}_{7}\right)\left(\mathrm{T}_{7}\right) & 3.1 & 40\end{array}$




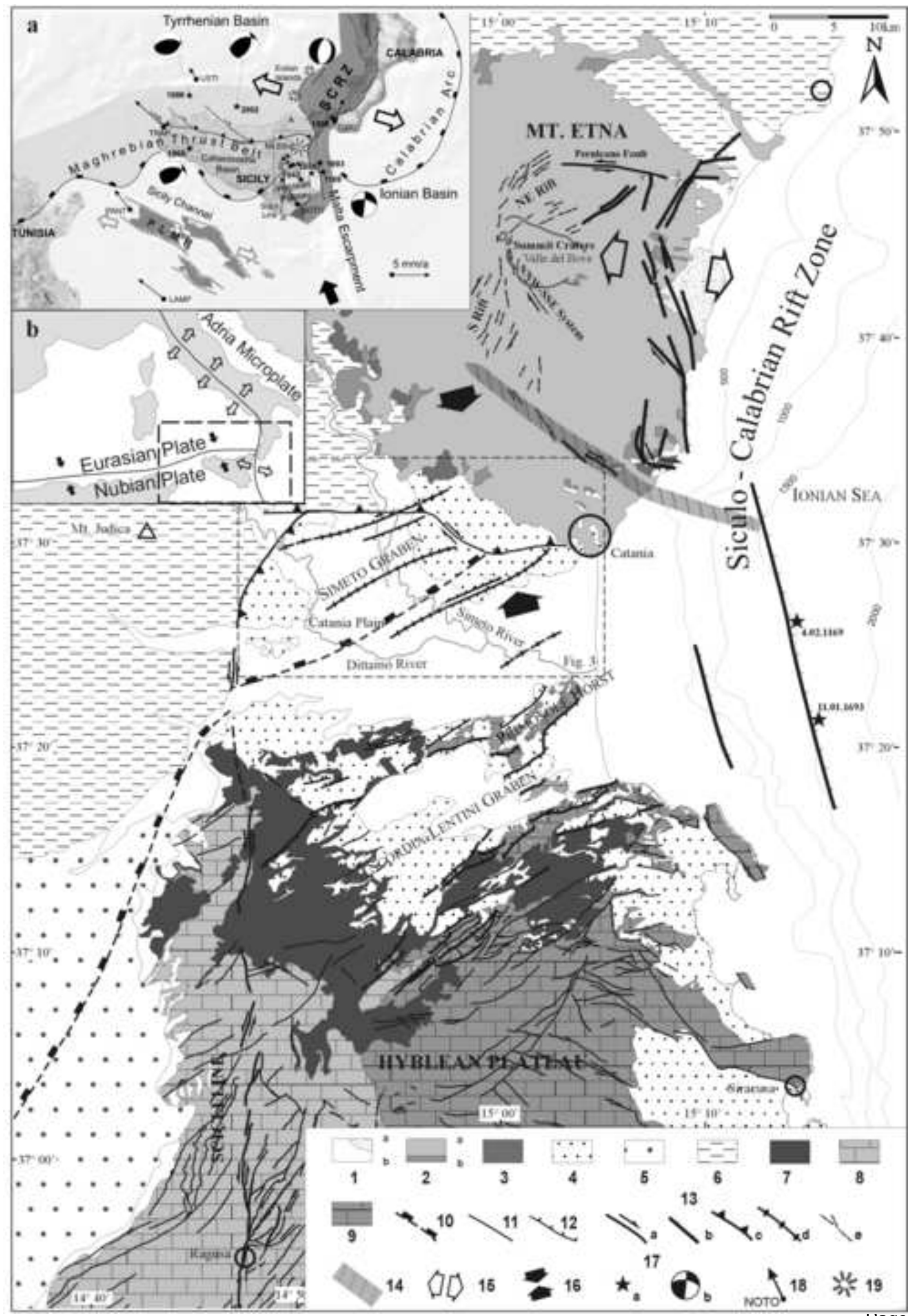




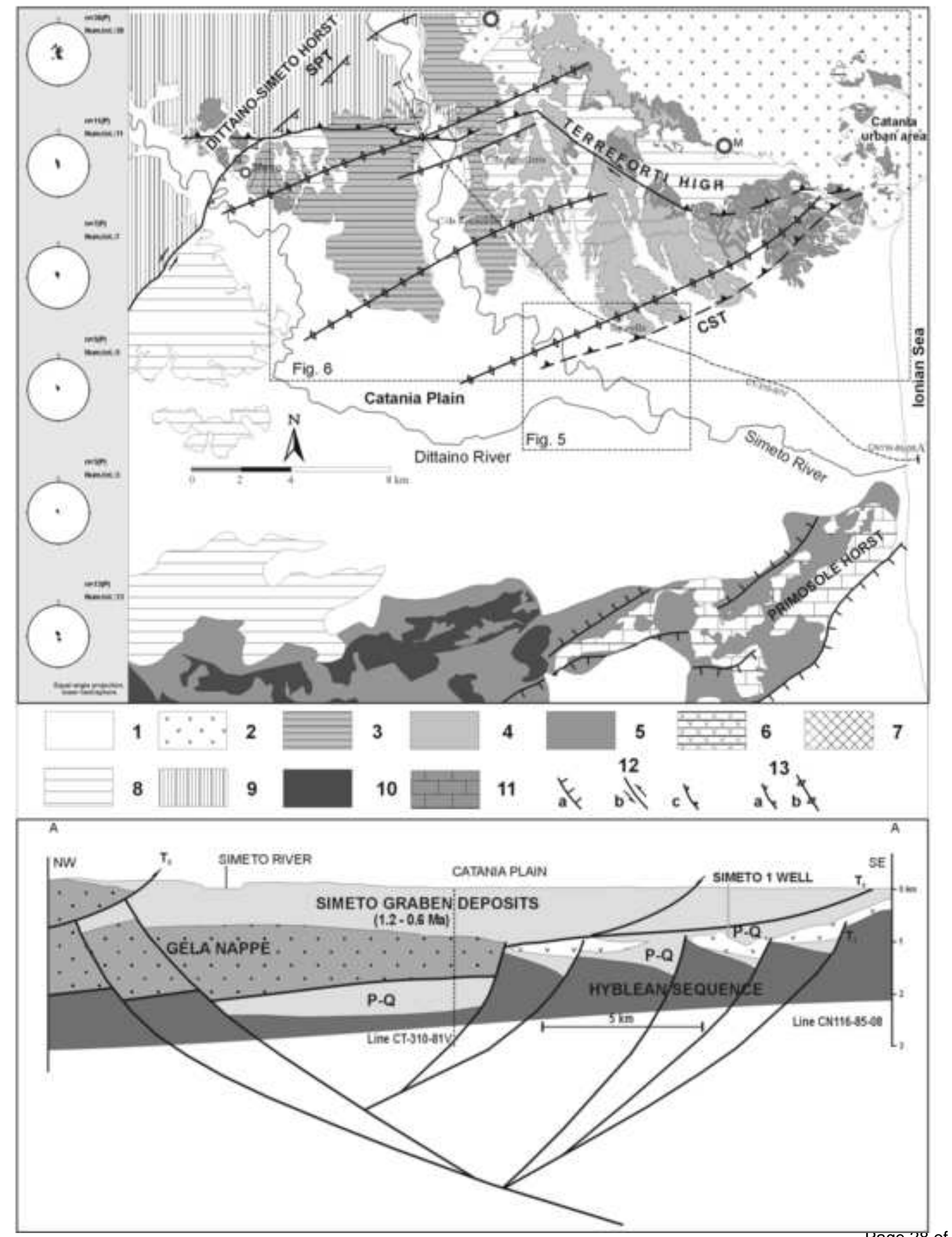




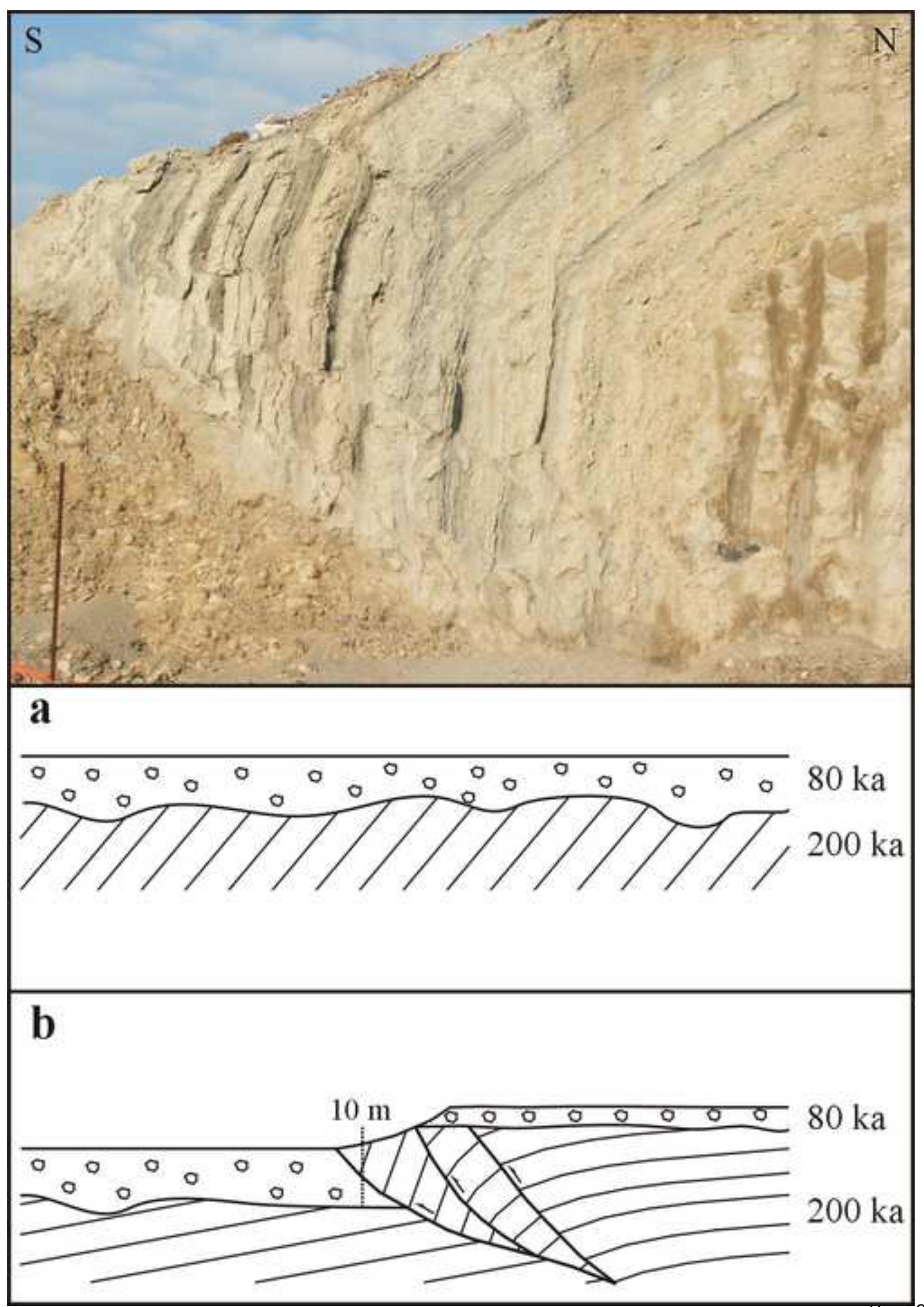

$S$

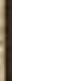

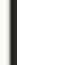




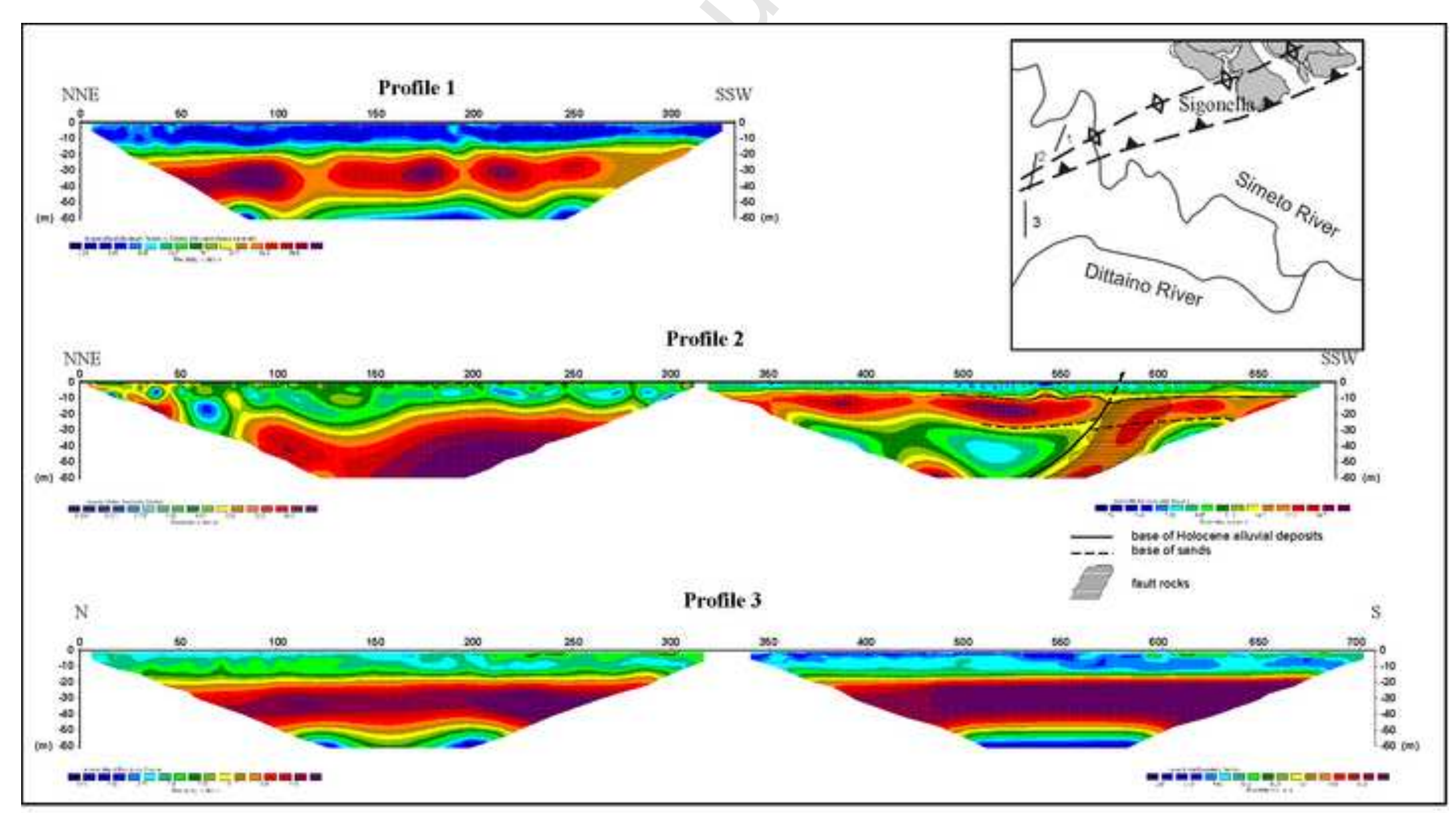

Profile 2

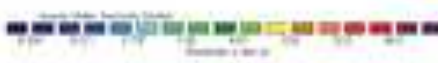

- bue of Hobecen allunal deposts base of andot

Profile 3

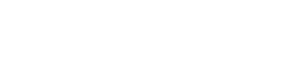




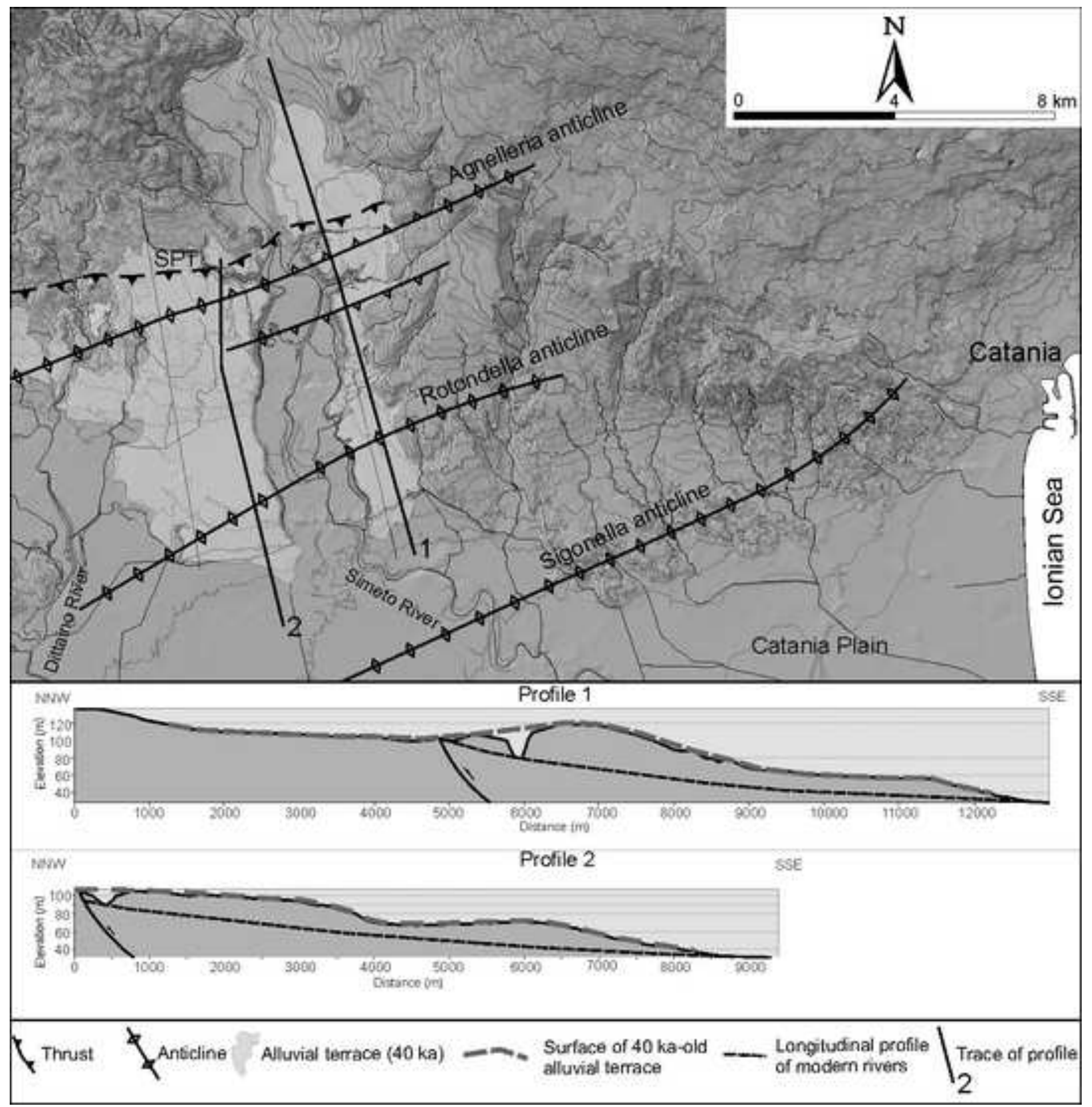




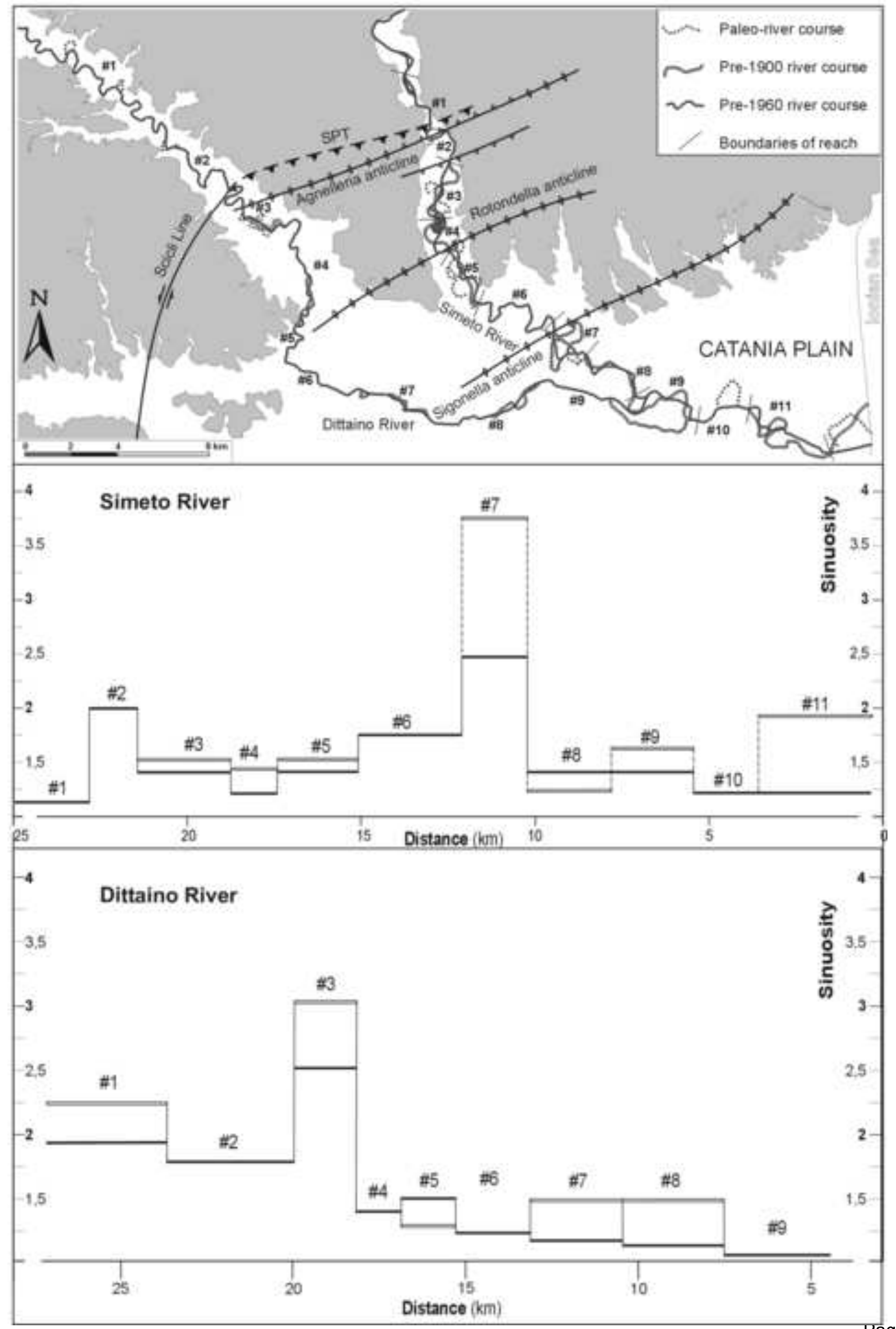




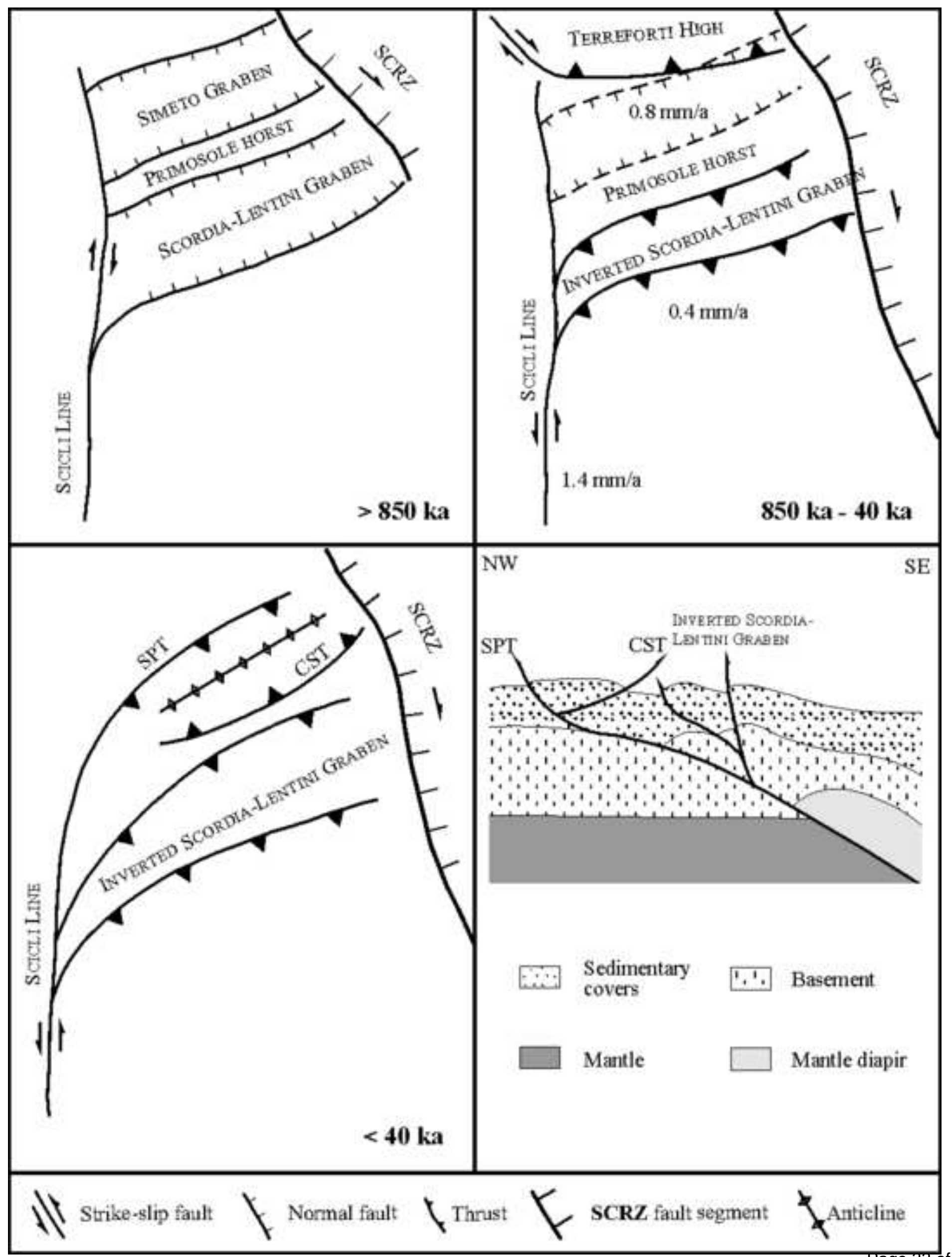




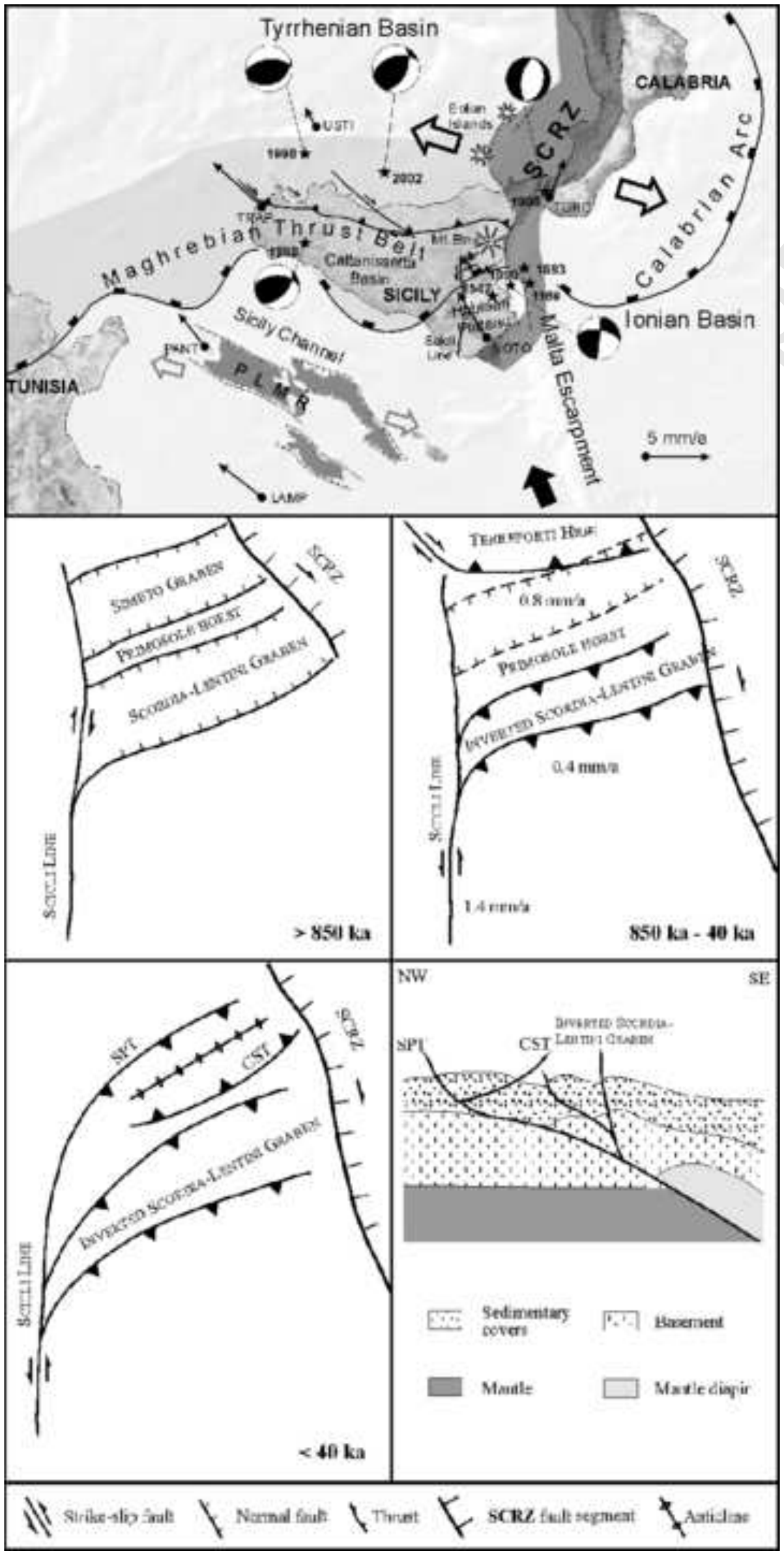

